\title{
Kemampuan Pemahaman Matematis Peserta Didik Melalui COOPERATIVE LEARNING TIPE PAIR CHECKS VS PROBLEM BASED LEARNING
}

\author{
Rypan Supriatna ${ }^{1)}$, Ekasatya Aldila Afriansyah ${ }^{2)}$ \\ 1),2) Institut Pendidikan Indonesia, Garut, Indonesia \\ E-mail:e_satya@yahoo.com
}

\begin{abstract}
Abstrak. Penggunaan model pembelajaran bisa digunakan sebagai perangsang minat dan motivasi belajar peserta didik agar bisa terlibat secara aktif dalam pembelajaran. Adapun tujuan penelitian ini untuk menganalisis perbedaan dan kualitas peningkatan kemampuan pemahaman matematis serta respon peserta didik antara yang menggunakan model pembelajaan kooperatif tipe Pair Checks dan model Problem Based Learning. Metode penelitian yang digunakan adalah metode kuasi eksperimen dengan menggunakan dua kelas sebagai sampel. Penelitian dilakukan di SMP Negeri 2 Cilawu tahun ajaran 2016/2017, kelas eksperimen I adalah kelas VII-G yang mendapatkan model pembelajaran kooperatif tipe Pair Checks dengan jumlah peserta didik sebanyak 32 orang dan kelas eksperimen II adalah kelas VII-H yang mendapatkan model Problem Based Learning dengan jumlah peserta didik sebanyak 32 orang. Materi yang digunakan dalam penelitian ini adalah Segiempat. Berdasarkan hasil analisis statistik yang dilakukan diperoleh kesimpulan: "Tidak terdapat perbedaan peningkatan kemampuan akhir yang signifikan antara peserta didik yang mendapatkan model pembelajaran kooperatif tipe Pair Check dan model Problem Based Learning”. sedangkan peningkatan kemampuan pemahaman matematis peserta didik dari kedua kelas dikategorikan tinggi. Respon peserta didik terhadap model pembelajaran kooperatif tipe Pair Check menghasilkan respon baik dan respon peserta didik terhadap model Problem Based Learning menghasilkan respon sangat baik
\end{abstract}

Kata kunci: Pemahaman Matematis, Kooperatif Tipe Pair Check, Problem Based Learning

\section{PENDAHULUAN}

Matematika masih dianggap sebagai pelajaran yang sulit sehingga berdampak pada rendahnya kemampuan pemahaman matematis peserta didik. Salah satu upaya untuk mengatasi kesulitan peserta didik dalam memahami dan menyelesaikan masalah matematika adalah dengan mengajarkan matematika secara menarik dan terhubung dunia nyata.

Peningkatan kualitas pembelajaran matematika perlu dilakukan tidak hanya semata-mata karna urgensi ilmu matematika, tetapi juga untuk meningkatkan kemampuan peserta didik Indonesia (Afriansyah, 2017). Penggunaan model pembelajaran kooperatif tipe Pair Checks dan Model pembelajaran Problem Based Learning adalah solusi dari masalah tersebut, model pembelajaran digunakan sebagai perangsang minat dan motivasi belajar peserta didik agar bisa terlibat secara aktif dalam pembelajaran, serta dapat meningkatkan kemampuan peserta didik.
Dari latar belakang di atas, maka rumusan masalah dalam penelitian ini adalah sebagai berikut.

1. Apakah terdapat perbedaan peningkatan kemampuan pemahaman matematis peserta didik antara yang mendapatkan model pembelajaran kooperatif tipe Pair Checks dengan model Problem Based Learning?

2. Bagaimana kualitas peningkatan kemampuan pemahaman matematis peserta didik yang mendapatkan model pembelajaran kooperatif tipe Pair Checks?

3. Bagaimana kualitas peningkatan kemampuan pemahaman matematis peserta didik yang mendapatkan model Problem Based Learning?

4. Bagaimana respon peserta didik terhadap model pembelajaran kooperatif tipe Pair Checks?

5. Bagaimana respon peserta didik terhadap model Problem Based Learning? 


\section{A - - Jurnal Pendidikan Matematika Indonesia \\ Volum 3 Nomor 1 bulan Maret 2018 Page 1 - 6 \\ p-ISSN: 2477-5967 e-ISSN: 2477-8443}

\section{KAJIAN PUSTAKA}

Kemampuan pemahaman matematis adalah kemampuan menyerap dan memahami ide-ide matematika. Adapun kemampuan pemahaman yang penulis ambil dalam penelitian ini adalah indikator dari Depdiknas (Rohman, 2009) antara lain:

. Dengan indikator sebagai berikut:

1) Menyatakan ulang sebuah konsep

2) Mengklarifikasi objek-objek menurut sifat-sifat tertentu (sesuai dengan konsepnya)

3) Menerapkan konsep secara algoritma.

4) Memberi contoh dan non contoh dari konsep yang dipelajari.

5) Menyajikan konsep dalam berbagai macam bentuk representasi matematika

6) Menggunakan, memanfaatkan, dan memilih prosedur atau operasi tertentu

7) Mengembangkan syarat perlu dan syarat cukup suatu konsep.

Beberapa penelitian relevan mengenai kemampuan pemahaman matematis yang telah dilakukan, yaitu:

1) Kemampuan pemahaman matematis siswa yang mendapatkan model pembelajaran kooperatif tipe Rotating Trio Exchange lebih baik dibandingkan dengan kemampuan pemahaman matematis yang mendapatkan pembelajaran konvensional (Nuraeni \& Afriansyah, 2016).

2) Terdapat perbedaan peningkatan kemampuan pemahaman matematis siswa antara yang mendapatkan model pembelajaran kooperatif teknik Numbered Head Together (NHT) dengan kancing gemerincing (Muna \& Afriansyah, 2016).

3) Kemampuan pemahaman matematis antara siswa yang mendapatkan model pembelajaran ATI lebih tinggi dari pada siswa yang mendapatkan model pembelajaran Konvensional (Pamungkas \& Afriansyah, 2017).

4) Terdapat perbedaan kemampuan pemahaman matematis antara siswa yang mendapatkan model pembelajaran Auditory Intellectually Repetition dan Problem Based Learning (Alan \& Afriansyah, 2017).

Menurut Huda (2013), "Pair Check merupakan model pembelajaran berkelompok antar dua orang atau berpasangan yang dipopulerkan oleh Spencer Kagen tahun 1990". Model pembelajaran kooperatif tipe Pair Check adalah suatu tipe pembelajaran kooperatif yang berpasangan yang memiliki tujuan untuk mendalami atau melatih materi yang dipelajari. Model ini menerapkan pembelajaran berkelompok yang menuntut kemandirian dan kemampuan peserta didik dalam menyelesaikan persoalan yang diberikan, sehingga dapat melatih rasa sosial peserta didik, kerja sama dan kemampuan memberi penilaian.

Menurut Tan (2003) dan Wee \& Kek (2012) menyatakan bahwa "Problem Based Learning adalah suatu pendekatan pembelajaran dengan membuat konfirmasi kepada pebelajar dengan masalah-masalah praktis atau pembelajaran yang dimulai dengan pemberian masalah dan memiliki konteks dengan dunia nyata". Menurut Hudojo (1988) Problem Based Learning adalah "Proses yang ditempuh oleh seseorang untuk menyelesaikan masalah yang dihadapinya sampai masalah itu tidak lagi menjadi masalah baginya".

Beberapa penelitian relevan mengenai PBL yang telah dilakukan, yaitu:

1) Peningkatan kemampuan pemecahan masalah matematis siswa yang mendapatkan pembelajaran PBL tergolong tinggi (Nadhifah \& Afriansyah, 2016).

2) Kualitas peningkatan kemampuan komunikasi matematis siswa untuk kelas PBL dengan menggunakan pendekatan RME berinterpretasi sedang (Alamiah \& Afriansyah, 2017).

3) Penerapan model pembelajaran Problem Based Learning (PBL) siswa lebih memahami masalah, merencanakan masalah, menyelesaikan masalah sesuai rencana, serta melakukan pengecekan kembali atau menafsirkan solusi (Yusri, 2018).

4) Keaktifan peserta didik dalam proses pembelajaran melalui Problem Based-Learning (PBL) lebih baik dibandingkan sebelum menggunakan Problem BasedLearning (PBL) (Julita, 2018).

\section{METODE PENELITIAN}

Dalam penelitian ini, model yang digunakan oleh peneliti adalah model Quasi Eksperimen dengan sampel sebanyak dua kelompok. Kelompok yang diberikan perlakuan model pembelajaran kooperatif tipe Pair Checks sebagai kelas eksperimen I dan kelompok yang diberikan perlakuan model Problem Based Learning sebagai kelas eksperimen II.

1. Populasi dan Sampel

Populasi dalam penelitian ini adalah peserta didik kelas VII. Sampel dalam penelitian ini diambil secara acak sebanyak dua kelas, yaitu kelas VII-G sebagai kelas eksperimen I dan kelas VII-H sebagai kelas eksperimen 2.

\section{Desain Penelitian}

Dengan mengambil dua kelas sebagai kelas eksperimen I yang menggunakan model pembelajaran kooperatif tipe Pair Checks dan kelas eksperimen II yang menggunakan model Problem Based Learning. Dengan menggunakan 
desain penelitian yang dikemukakan oleh Arikunto (2010) yang dinamakan Pretest and Posttest Group adalah sebagai berikut:

\begin{tabular}{cccc}
\hline & Pretest & Perlakuan & Posttest \\
\hline $\mathrm{E}_{1}$ & $\mathrm{O}$ & $\mathrm{X}$ & $\mathrm{O}$ \\
$\mathrm{E}_{2}$ & $\mathrm{O}$ & $\mathrm{Y}$ & $\mathrm{O}$ \\
\hline
\end{tabular}

Keterangan :

$\mathrm{E}_{1}=$ Kelas eksperimen I

$\mathrm{E}_{2}=$ Kelas eksperimen II

$\mathrm{O}=$ Tes awal (pretest) dan tes akhir (posttest)

$\mathrm{X}=$ Pembelajaran menggunakan model Pair Checks

$\mathrm{Y}=$ Pembelajaran menggunakan model Problem Based Learning

\section{Instrumen Penelitian}

a. Tes

Bentuk instrumen dari penelitian ini adalah tes uraian (esai). Bentuk tes esai merupakan sejenis tes kemajuan belajar yang memerlukan jawaban yang bersifat pembahasan atau uraian kata-kata, dengan singkat bahwa tes esai mempunyai daya kreativitas tinggi (Arikunto, 2010).

\section{b. Angket}

Mahmud (2013) menyatakan bahwa "angket adalah teknik pengumpulan data dengan menyerahkan daftar pernyataan untuk diisi oleh responden". Teknik pengumpulan data berupa angket ini digunakan untuk mengukur respon dan sikap peserta didik terhadap pembelajaran yang dilakukan juga untuk mengukur nilai variabel yang diteliti.

\section{HASIL DAN PEMBAHASAN}

Penelitian ini bertujuan untuk menganalisis Perbedaan Peningkatan Kemampuan Pemahaman Matematis Peserta Didik Antara Yang Mendapatkan Model Pembelajaran Kooperatif Tipe Pair Checks Dan Problem Based Learning. Untuk itu penulis melakukan tes awal (Pretest) dan tes akhir (Posttest). Adapun data yang diperoleh sebagai berikut:
TABEL I

Uji PERBEDAAN KEMAMPUAN AWAL

\begin{tabular}{ccccc}
\hline \multirow{2}{*}{ Keterangan } & \multicolumn{2}{c}{$\begin{array}{c}\text { Kelas Pair } \\
\text { Checks }\end{array}$} & \multicolumn{2}{c}{$\begin{array}{c}\text { Kelas Problem } \\
\text { Based Learning }\end{array}$} \\
\cline { 2 - 5 } & Pretest & Posttest & Pretest & Posttest \\
\hline Jumlah & 32 & 32 & 32 & 32 \\
peserta & & & & \\
didik & & & & \\
Skor Ideal & 24 & 24 & 24 & 24 \\
Nilai & 7 & 18 & 8 & 15 \\
Terkecil & & & & \\
Nilai & 14 & 24 & 13 & 24 \\
Terbesar & & & & \\
Rata-rata & 10.875 & 20.781 & 10.50 & 20.437 \\
Simpangan & 1.601 & 1.913 & 1.344 & 4.553 \\
Baku & & & & \\
\hline
\end{tabular}

Setelah dilakukan uji perbedaan kemampuan awal. Dari hasil perhitungan uji $\mathrm{t}^{\prime}$ diperoleh $\mathrm{t}_{\text {hitung }}=2,7472$ lebih besar dari $t_{\text {tabel }}=2,040$ maka Ho ditolak sehingga dapat disimpulkan bahwa Terdapat perbedaan kemampuan awal yang signifikan antara peserta didik yang mendapatkan model pembelajaran kooperatif tipe Pair Checks dan Problem Based Learning.

Terdapat perbedaan kemampuan awal peserta didik, kemudian langkah selanjutnya Uji Perbedaan Gain Ternormalisasi. Dalam analisis data Uji Perbedaan Gain Ternormalisasi penelitian menggunakan Uji Man Whitney. Dengan menggunakan uji dua pihak dan taraf signifikan 0,05 diperoleh nilai $\mathrm{Z}_{\text {tabel }}=\mathrm{Z}_{0,05}(1-0,05)=\mathrm{Z}_{0,475}=1,96$; karena nilai $Z_{\text {hitung }}=0,658$ berada pada daerah penerimaan Ho yaitu: - $Z_{\text {tabel }} \leq Z_{\text {hitung }} \leq Z_{\text {tabel }}=-1,96 \leq 0,658 \leq 1,96$ dapat di simpulkan bahwa: Tidak terdapat perbedaan kemampuan awal yang signifikan antara peserta didik yang mendapatkan model pembelajaran kooperatif tipe Pair Checks dan model Problem Based Learning.

Setelah menganalisis perbedaan kemampuan pemahaman matematis, maka dilanjutkan untuk menganalisis peningkatan kemampuan matematis peserta didik antara yang mendapatkan model pembelajaran kooperatif tipe Pair Checks dan Problem Based Learning. Adapun data yang diperoleh yaitu sebagai berikut:

TABEL III

Data Skor Kedua Model Pembelajaran

\begin{tabular}{ccc}
\hline Keterangan & $\begin{array}{c}\text { Pair } \\
\text { Checks }\end{array}$ & $\begin{array}{c}\text { Problem Based } \\
\text { Learning }\end{array}$ \\
\hline Skor Ideal & 24 & 24 \\
Rata-Rata & 0,7241 & 0,7596 \\
Simpangan & 0,1846 & 0,1471 \\
Xmaks & 1,000 & 1,000 \\
Xmin & 0,273 & 0,688 \\
Kategori & Tinggi & Tinggi \\
\hline
\end{tabular}




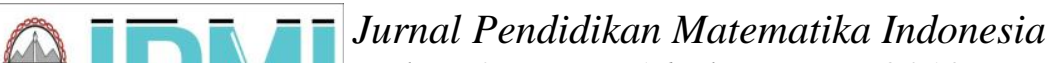 \\ Volum 3 Nomor 1 bulan Maret 2018 Page 1 - 6 \\ p-ISSN: 2477-5967 e-ISSN: 2477-8443}

Dari data di atas maka dapat disimpulkan bahwa kelas Pair Checks mengalami peningkatan dengan interpretasi yang tinggi di peroleh dari hasil rata-rata nilai gain yaitu sebesar 0,7241. Kemudian, untuk kelas Problem Based Learning mengalami peningkatan dengan interpretasi yang sedang diperoleh dari nilai rata-rata nilai gain yaitu sebesar 0,7596 .

Setelah menganalisis data gain dari kelas Pair Checks dan Problem Based Learning, kemudian dilanjutkan untuk menganalisis sikap peserta didik terhadap kedua model pembelajaran.

Dilihat dari jumlah nilai keseluruhan yaitu 1938 maka interpretasi skala sikap menunjukkan skala tanggapan berada dikategori baik. Dapat disimpulkan bahwa sikap peserta didik terhadap pembelajaran dengan menggunakan model pembelajaran kooperatif tipe Pair Checks menunjukkan sikap baik.

Adapun data yang diperoleh yaitu sebagai berikut:

TABEL IIIII

INTERPRETASI SKALA SIKAP PESERTA DIDIK SETIAP INDIKATOR MODEL PEMBELAJARAN KOOPERATIF TIPE PAIR CHECKS

\begin{tabular}{|c|c|c|}
\hline Indikator & $\begin{array}{l}\text { Skor } \\
\text { Total }\end{array}$ & Keterangan \\
\hline $\begin{array}{c}\text { Menunjukkan } \\
\text { kesukaan } \\
\text { terhadap } \\
\text { model }\end{array}$ & $404 \quad 1848$ & Baik Baik \\
\hline $\begin{array}{c}\text { Menunjukkan } \\
\text { persetujuan } \\
\text { terhadap } \\
\text { aktivitas } \\
\text { pembelajaran }\end{array}$ & 758 & Baik \\
\hline $\begin{array}{l}\text { Menunjukkan } \\
\text { keaktifan pada } \\
\text { saat } \\
\text { pembelajaran }\end{array}$ & 686 & Baik \\
\hline
\end{tabular}

Dari tabel tersebut, didapat bahwa interpretasi skala sikap peserta didik setiap indikator tersebut mendapatkan skor total 1848, sehingga dapat disimpulkan bahwa, interpretasi skala sikap peserta didik setiap indikator terhadap model pembelajaran kooperatif tipe Pair Checks mendapat tanggapan sikap yang baik.

TABEL IVV

INTERPRETASI SKALA SIKAP SETIAP KATEGORI MODEL PEMBELAJARAN KOOPERATIF TIPE PAIR CHECKS

\begin{tabular}{cccc}
\hline No & Kategori & $\begin{array}{c}\text { Banyak } \\
\text { Peserta } \\
\text { Didik }\end{array}$ & Persen \\
\hline 1 & Jelek & 2 & 6,25 \\
2 & Baik & 24 & 75 \\
3 & Sangat Baik & 6 & 18,75 \\
& Jumlah & 32 & 100 \\
\hline
\end{tabular}

Interpretasi skala sikap peserta didik dimana setiap peserta didik yang mendapatkan kategori jelek sebanyak 2 orang dengan pesentase $6,25 \%$, kategori baik sebanyak 24 orang dengan persentase $75 \%$, dan kategori sangat baik sebanyak 6 orang dengan persentase $18,75 \%$, dimana peserta didik yang mendapatkan kategori baik ini mendapatkan persentase paling tinggi.

Sehingga dapat disimpulkan bahwa, interpretasi skala sikap setiap individu mendapatkan tanggapan yang baik dari setiap peserta didik terhadap pembelajaran menggunakan model pembelajaran kooperatif tipe Pair Checks. Interpretasi skala sikap peserta didik tersebut mendapatkan skor total 2039, sehingga dapat disimpulkan bahwa, interpretasi skala sikap peserta didik secara umum terhadap model Problem Based Learning mendapat tanggapan sikap yang baik.

TABEL V

INTERPRETASI SKALA SIKAP PESERTA DIDIK SETIAP INDIKATOR PROBLEM BASED LEARNING

\begin{tabular}{|c|c|c|c|}
\hline Indikator & $\begin{array}{l}\text { Skor } \\
\text { Total }\end{array}$ & Keter & ngan \\
\hline $\begin{array}{c}\text { Menunjukkan } \\
\text { kesukaan } \\
\text { terhadap } \\
\text { model }\end{array}$ & $226 \quad 2039$ & $\begin{array}{c}\text { Sangat } \\
\text { Baik }\end{array}$ & $\begin{array}{c}\text { Sangat } \\
\text { Baik }\end{array}$ \\
\hline $\begin{array}{l}\text { Menunjukkan } \\
\text { persetujuan } \\
\text { terhadap } \\
\text { aktivitas } \\
\text { pembelajaran }\end{array}$ & 1152 & $\begin{array}{c}\text { Sangat } \\
\text { Baik }\end{array}$ & \\
\hline $\begin{array}{l}\text { Menunjukkan } \\
\text { keaktifan } \\
\text { pada saat } \\
\text { pembelajaran }\end{array}$ & 661 & Baik & \\
\hline
\end{tabular}

Dari tabel tersebut, didapat bahwa interpretasi skala sikap peserta didik setiap indikator tersebut mendapatkan skor total 2039, sehingga dapat disimpulkan bahwa, interpretasi skala sikap peserta didik setiap indikator terhadap model Problem Based Learning mendapat tanggapan sikap sangat baik.

TABEL VI

INTERPRETASI SKALA SIKAP SETIAP KATEGORI PROBLEM BASED LEARNING

\begin{tabular}{|c|c|c|c|}
\hline No & Kategori & $\begin{array}{c}\text { Banyak } \\
\text { Peserta } \\
\text { Didik }\end{array}$ & Persen \\
\hline 1 & Jelek & 1 & 3,125 \\
\hline 2 & Baik & 13 & 40,625 \\
\hline 3 & $\begin{array}{c}\text { Sangat } \\
\text { Baik }\end{array}$ & 18 & 56,25 \\
\hline \multicolumn{2}{|c|}{ Jumlah } & 32 & 100 \\
\hline
\end{tabular}

Interpretasi skala sikap peserta didik dimana setiap peserta didik yang mendapatkan kategori jelek sebanyak 1 
orang dengan pesentase $3,125 \%$, kategori baik sebanyak 13 orang dengan persentase $40,625 \%$, dan kategori sangat baik sebanyak 18 orang dengan persentase $56,25 \%$, dimana peserta didik yang mendapatkan kategori sangat baik ini mendapatkan persentase paling tinggi.

Sehingga dapat disimpulkan bahwa, interpretasi skala sikap setiap individu mendapatkan tanggapan yang sangat baik dari setiap peserta didik terhadap pembelajaran menggunakan model Problem Based Learning.

Selama pelaksanaan pembelajaran, peneliti menemukan beberapa data penting, diantaranya penggunaan model pembelajaran kooperatif tipe Pair Checks pada pembelajaran matematika merupakan hal baru bagi peserta didik SMP Negeri 2 Cilawu Kelas VII-G. Hal ini menciptakan suasana pembelajaran yang lain dari sebelumnya, pada umumnya selama ini kebiasaan belajar peserta didik lebih sering belajar secara individual. Pada pembelajaran menggunakan model pembelajaran kooperatif tipe Pair Check, peserta didik harus menyelesaikan LKS yang telah diberikan, dan memberi reward kepada kelompok yang lebih baik.

Penggunaan model pembelajaran kooperatif tipe Pair Checks membuat peserta didik lebih aktif dan lebih dapat memahami materi. peserta didik lebih mendalami dan melatih materi yang dipelajari. peserta didik dituntut untuk bisa mandiri dan kemampuan peserta didik dalam menyelesaikan soal yang diberikan, sehingga dapat melatih rasa sosial peserta didik, kerja sama dan kemampuan memberi penilaian. sehingga mereka lebih mudah memahami materi yang dipelajari dan tujuan pembelajaran pun akan lebih cepat tercapai.

Pembelajaran menggunakan model pembelajaran kooperatif tipe Pair Checks juga membantu peserta didik dalam mengembangkan kemampuan pemahaman matematis. Meningkatkan kerja sama antar peserta didik yang sebelumnya tidak terlalu sering belajar secara berkelompok.

Adapun peserta didik yang belum paham ketika guru menyampaikan materi ketika saat mengerjakan soal dalam penerapan model pembelajaran kooperatif tipe Pair Checks peserta didik dapat dibantu oleh pasangannya atau biasa disebut pengajaran teman sebaya. Disamping pembelajaran itu juga model pembelajaran kooperatif tipe Pair Checks secara tidak langsung melatih peserta didik berkomuniksi dengan baik karena peserta didik lebih aktif dan menimbulkan sikap percaya diri serta berani mengemukakan pendapatnya dalam melakukan aktivitas belajar, guru pun memberikan poin tambahan bagi peserta didik yang aktif sehingga peserta didik semakin bersemangat dalam melakukan aktivitas di dalam kelas.

Pembelajaran menggunakan model pembelajaran kooperatif tipe Pair Checks memiliki kelemahan dalam penerapannnya. Pertama, membutuhkan waktu yang memadai, karena pada saat penerapannya peneliti merasa kesulitan ketika peserta didik sedang mengerjakan LKS waktu pembelajaran sudah selesai. Kedua, mata pelajaran matematika berada di jam-jam rawan seperti jam masuk sesudah istirahat dan sesudah mata pelajaran olahraga.

Pada pembelajaran menggunakan model Problem Based Learning, peneliti mengambil gaya pembelajaran dengan berdiskusi secara berkelompok dan meminta peserta didik untuk presentasi, serta menyelesaikan LKS yang telah dilengkapi dengan gambar-gambar dan soal cerita yang menarik untuk dicari solusinya secara berkelompok.

Penggunaan model Problem Based Learning dapat menarik minat dan perhatian peserta didik dalam belajar. secara tepat membantu peserta didik memahami dan megingat isi informasi sehingga tujuan pembelajaran dapat tercapai. Peserta didik dapat mengumpulkan informasi menetapkan strategi dalam memecahkan masalah sehingga dapat mendorong kemampuan berpikir kreatif. Pokok materi yang dipelajari tidak harus memiliki tingkat kesulitan yang tinggi karena dapat menakuti peserta didik

Pembelajaran menggunakan model Problem Based Learning membuat peserta didik lebih memahami materi dan menimbulkan sikap percaya diri serta berani mengemukakan pendapatnya dalam melakukan aktivitas belajar, guru pun memberikan poin tambahan dan reward bagi peserta didik yang aktif sehingga peserta didik semakin bersemangat dalam melakukan aktivitas di dalam kelas.

Kelemahan dalam penerapan model Problem Based Learning adalah mata pelajaran matematika berada di jam rawan seperti jam pelajaran sesudah olahraga dan jam terakhir, sehingga dalam penerapannya peserta didik kurang efektif dan kondusif. Kelas ini berada di dekat kantin sekolah sehingga ada peserta didik yang selalu keluar masuk kelas membuat tidak nyaman kelas saat pembelajaran. Sedikitnya ada peserta didik yang selalu bermain hp ketika diskusi kelompok dilakukan dengan alasan mencari sumber atau bahan ajar mengenai materi.

\section{SIMPULAN}

Berdasarkan hasil penelitian dan pembahasan secara keseluruhan, maka dapat ditarik simpulan sebagai berikut:

1. Berdasarkan pengolahan data maka dapat disimpulkan tidak terdapat perbedaan peningkatan kemampuana akhir yang signifikan antara peserta didik yang mendapatkan model pembelajaran kooperatif tipe Pair Checks dan model Problem Based Learning. 


\section{- - - Jurnal Pendidikan Matematika Indonesia \\ Volum 3 Nomor 1 bulan Maret 2018 Page 1 - 6 \\ p-ISSN: 2477-5967 e-ISSN: 2477-8443}

2. Kemampuan pemahaman matematis peserta didik setelah diberikan model pembelajaran kooperatif tipe Pair Checks rata-rata berinterpretasi tinggi.

3. Kemampuan pemahaman matematis peserta didik setelah diberikan model Problem Based Learning ratarata berinterpretasi tinggi.

4. Tanggapan peserta didik terhadap model pembelajaran kooperatif tipe Pair Checks secara umum berinterpretasi baik.

5. Tanggapan peserta didik terhadap model Problem Based Learning secara umum berinterpretasi sangat baik.

\section{DAFTAR PUSTAKa}

Afriansyah, E. A. (2017). Desain Lintasan Pembelajaran Pecahan melalui Pendekatan Realistic Mathematics Education. Jurnal Mosharafa, 6 (3), 463-474.

Alamiah, U. S. dan Afriansyah, E. A. (2017). Perbandingan Kemampuan Komunikasi Matematis Siswa Antara yang Mendapatkan Model Pembelajaran Problem Based Learning dengan Pendekatan Realistic Mathematics Education dan Open-Ended. Jurnal Mosharafa, 6 (2), 207-216.

Alan, U. F. dan Afriansyah, E.A. (2017) Kemampuan Pemahaman Matematis Siswa Melalui Model Pembelajaran Auditory Intellectualy Repetition Dan Problem Based Learning. Jurnal Pendidikan Matematika UNSRI, 11 (1), 67-78.

Arikunto,S. (2010). Prosedur Penelitian Pendekatan Suatu Praktik. Jakarta: PT. Rineka Cipta.

Huda, M. (2013). Model-model Pengajaran dan Pembelajaran. UPI. Bandung: tidak diterbitkan

Hudojo, H. (1988). Strategi Pembelajaran Matematika. Malang: Balai Pustaka.

Julita. (2018). Peningkatan Kemampuan Pemecahan Masalah dan Hasil Belajar Matematika melalui Problem Based-Learning. Jurnal Mosharafa, 7 (1), 143-154.
Mahmud. (2013). Metode Penelitian Pendidikan. Bandung: CV. Pustaka Setia.

Muna, D. N. dan Afriansyah, E. A. (2016). Peningkatan Kemampuan Pemahaman Matematis Siswa melalui Pembelajaran Kooperatif Teknik Kancing Gemerencing dan Number Head Together. Jurnal Mosharafa, 5 (2), 169-176.

Nadhifah, G. dan Afriansyah, E. A. (2016). Peningkatan Kemampuan Pemecahan Masalah Matematis Siswa dengan Menerapkan Model Pembelajaran Problem Based Learning dan Inquiry. Jurnal Mosharafa, 5 (1), 33-44.

Nuraeni, Y. dan Afriansyah, E. A. (2016). Peningkatan Kemampuan Pemahaman Matematis Siswa Melalui Pembelajaran Kooperatif Tipe Rotating Trio Exchange. Jurnal Inovasi Pendidikan Dasar, 1 (2), 85-94.

Pamungkas, Y. dan Afriansyah, E. A. (2017). Aptitude Treatment Interaction terhadap Kemampuan Pemahaman Matematis Siswa. Jurnal Pendidikan Matematika RAFA, 3 (1), 122-130.

Rohman, A. (2009). Upaya peningkatan pemahaman konsep bilangan bulat dengan menggunakan alat peraga. Skripsi STKIP Garut Pendidikan Matematika: tidak diterbitkan

Tan, O. (2003). Problem Based Learning Innovation: Using Problem to Power Learning in 21st Century, thompson Learning.

Wee K. \& Kek. (2002). Authentic Problem Based learning: Rewriting Business Education. Prentice Hall.

Yusri, A. Y. (2018). Pengaruh Model Pembelajaran Problem Based Learning terhadap Kemampuan Pemecahan Masalah Matematika Siswa Kelas VII di SMP Negeri Pangkajene. Jurnal Mosharafa, 7 (1), 51-62. 